\title{
15 agbiotech firms lost \$126.4 million last year
}

NEW YORK-Two U.S. agbiotech companies reached the black last year, as Idexx (Portland, ME) took home $\$ 4.9$ million and Syntro (Lenexa, KS) brought in $\$ 435,000$. Overall, though, Bio/Technology's tally of 1992 year-end results shows that 15 surveyed agbiotech companies lost $\$ 126.4$ million last year, or $\$ 8.4$ million apiece, on average. This compares unfavorably with eight surveyed pesticide and seed companies that had profits of $\$ 2.1$ billion in 1992, or an average of $\$ 2.56 .1$ million each. DuPont (Wilmington, DE) was the leader among these companics, taking home $\$ 975$ million last year.

Agbiotech firms pumped up their sales in 1992. The 15 firms brought in $\$ 184.6$ million last year, which averaged out to $\$ 12.3$ million a company, a 61.4 percent increase over 1991. Idexx led the pack, with 1992 sales of \$57.7 million, while Mycogen (San Diego, CA) followed, amassing $\$ 34$ million in sales last year.

The cight pesticide and seed companies, for their part, saw sales rise just 0.2 percent last year, compared
TABLE 1. 1992 year-end results.

\begin{tabular}{|c|c|c|c|c|}
\hline & \multicolumn{2}{|c|}{ SALES } & \multicolumn{2}{|c|}{ PROFITS } \\
\hline & $\begin{array}{r}\text { Latest FY } \\
\text { (\$ Millions) }\end{array}$ & $\begin{array}{r}\text { Change } \\
\text { From Last } \\
\text { FY }(\%)\end{array}$ & $\begin{array}{r}\text { Latest FY } \\
\text { (\$ Millions) }\end{array}$ & $\begin{array}{r}\text { Change } \\
\text { From Last } \\
\text { FY }(\%)\end{array}$ \\
\hline AGBIOTECH COMPANIES & 1.231 & -60 & -7.033 & NM \\
\hline $\begin{array}{l}\text { Agridyne Technologies } \\
\text { biosys }\end{array}$ & 4.554 & 316 & -3.869 & $\begin{array}{l}\text { NM } \\
\text { NM }\end{array}$ \\
\hline Calgene $(6 / 92)$ & 21.877 & -16 & -18.616 & NM \\
\hline Crop Genetics International & 3.151 & 108 & -6.945 & NM \\
\hline DNA Plant Technology* & 11.962 & 10 & -18.161 & NM \\
\hline DNX & 7.450 & 141 & -5.970 & NM \\
\hline Ecogen & 8.028 & 29 & -21.366 & NM \\
\hline EcoScience $(6 / 92)$ & 0.147 & -25 & -5.315 & NM \\
\hline Embrex & 0.699 & 628 & -5.480 & NM \\
\hline Escagenetics (3/92) & 1.686 & -33 & -3.619 & NM \\
\hline Idexx Labs & 57.653 & 89 & 4.923 & 56 \\
\hline Mycogen & 33.994 & 86 & -30.370 & NM \\
\hline Neogen $(5 / 92)$ & 6.627 & 11 & -0.818 & NM \\
\hline Ringer (9/92) & 20.338 & -4 & -4.239 & NM \\
\hline Syntro (9/92) & 5.177 & 29 & 0.435 & NM \\
\hline Total & 184.574 & NA & -126.443 & NA \\
\hline Average & 12.305 & 61.4 & -8.430 & NM \\
\hline \multicolumn{5}{|c|}{ PESTICIDE AND SEED COMPANIES } \\
\hline American Cyanamid & $5,267.500$ & 6 & 395.100 & 10 \\
\hline Dekalb Genetics (8/92) & 300.200 & 9 & 10.000 & -36 \\
\hline Dow Chemical" & $18,971.000$ & 1 & 276.000 & -71 \\
\hline DuPont & $37,799.000$ & -2 & 975.000 & -31 \\
\hline FMC & $3,973.663$ & 2 & 192.600 & 11 \\
\hline Monsanto & $7,763.000$ & -2 & -126.000 & -153 \\
\hline Pioneer Hi-Bred Internationa & 32) $1,261.805$ & 12 & 152.160 & 46 \\
\hline Rohm \& Haas* & $3,063.400$ & 11 & 173.900 & 7 \\
\hline Total & $78,399.568$ & NA & $2,048.76$ & NA \\
\hline Average & $9,799.946$ & 0.2 & 256.095 & -45.2 \\
\hline
\end{tabular}

NM Indicates that revenues include nonoperating income.
NA means not meaningful.
Source:
to 1991. Total sales came to $\$ 78.4$ billion in 1992, for an average of $\$ 9.8$ billion a company. As with profits. DuPont led the way, with $\$ 37.8$ billion in 1992 sales.

Among agbiotech companies, Embrex (Research Triangle Park. NC) showed the biggest sales jump last year, a 628 percent leap over 1991. Runner-up hiosys' (Palo Alto, CA) sales soared 316 percent last year. compared to 1991. Pioncer Hi-Bred International (Des Moines, IL) led the pesticide and seed companies, with a 12 percent sales increase from 1991 to 1992. BiolTechnology includes all operating revenues in its sales definition, including contractresearch payments.

-B.J. Spalding

\section{FDA advisory panel mooooves Monsanto's BST}

WASHINGTON. D.C.-When used to augment milk production by dairy cows, Sometribove, Monsanto's (St. Louis, MO) version of bovine somatotropin (BST), increases the incidence of mastitisinfection-associated inflammation of cow milk glands-but does not pose a significant risk to public health. That's what the Food and Drug Administration's (FDA. Bethesda, MD) Veterinary Medicine Advisory Committee recently told FDA officials. Although the committee's conclusions appear to smooth the path for quick approval of BST. tight-lipped FDA officials and recurrent rumors about political uncasiness concerning BST cast doubt on the outcome and its timetable within the agency.

Several other companies-including American Cyanamid (Wayne. NJ). Eli Lilly (Indianapolis, IN). and Upjohn (Kalamazoo, MI)-are developing and testing similar ver- sions of BST, also known as bovine growth hormone, for its ability to increasc milk production by about 20 percent. However, the Veterinary Medicine Advisory Committee considered only the Monsanto product.

Gerald Guest, director of FDA's Center for Veterinary Medicine, formally asked the advisory panel to address several questions pertaining to BST's effect on mastitis. Dairy farmers often treat such in- 